
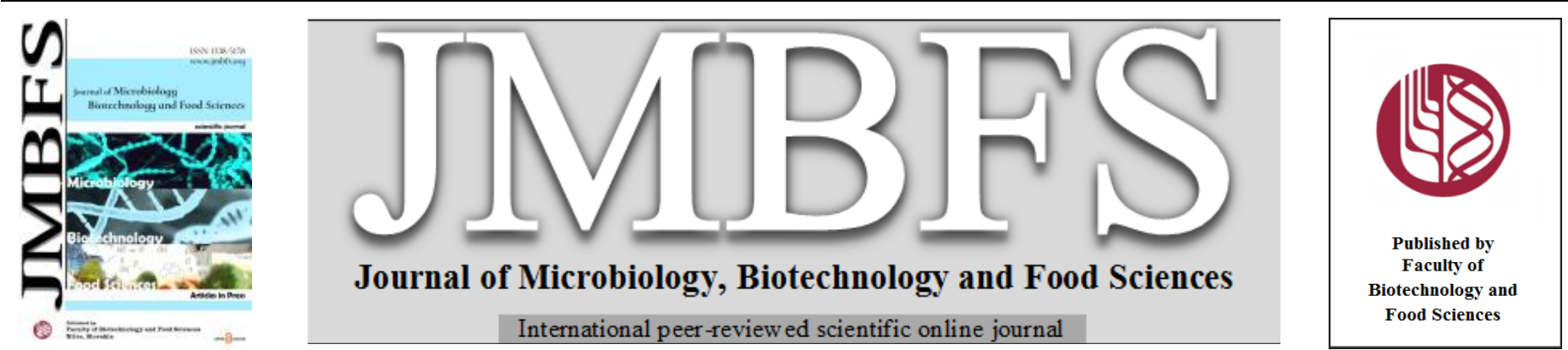

\title{
THE PROBIOTIC AND NUTRITIONAL CONTENT OF SOURO, AN IRANIAN TRADITIONAL FOOD
}

\author{
Milad Mohkam ${ }^{1,2}$, Shiva Ghasemi Firoozabadi ${ }^{3}$, Younes Ghasemi ${ }^{2,3,4}$, Ahmad Gholami $^{2,3,4 *}$ \\ Address(es): \\ ${ }^{1}$ Allergy Research Center, Shiraz University of Medical Sciences, Shiraz, Iran. \\ ${ }^{2}$ Biotechnology Research Center, Shiraz University of Medical Sciences, Shiraz, Iran. \\ ${ }^{3}$ Department of Pharmaceutical Biotechnology, School of Pharmacy, Shiraz University of Medical Sciences, Shiraz, Iran. \\ ${ }^{4}$ Pharmaceutical Science Research Center, Shiraz University of Medical Sciences, Shiraz, Iran.
}

*Corresponding author: Gholami@sums.ac.ir

https://doi.org/10.55251/jmbfs.2627

\section{ARTICLE INFO}

Received 5. 2. 2021

Revised 4. 9. 2021

Accepted 13. 9. 2021

Published 1. 2. 2022

Regular article OPEN $\partial_{\text {ACCESS }}$

\begin{abstract}
Probiotic foods are products containing adequate amounts of live and specific microorganisms that confer benefit to human health. This research was performed to spotlight on the nutritional value evaluation as well as isolation and probiotic characterization of lactic acid bacteria (LAB) isolated from native food "Souro" belonging to Iran. The isolated LABs were investigated in vitro for potential probiotic features based on their acidic $\mathrm{pH}$ tolerance, bile-salt resistance, hydrophobicity, autoaggragation, production of amylase and protease as well as antibiotic susceptibility test. Results showed that Souro had high content of protein $(51 \pm 0.16 \%$, ) and total lipid was $11.18 \pm$ $0.38 \%$. Most of isolates were able to produce protease and amylase. From the best potential probiotic isolates, $16 \mathrm{~S}$ rRNA gene sequencing disclosed Lactobacillus plantarum, L. hilgardii, L. casei, L. fermentum and Weissella paramesenteroides. Thus, good physiological traits and safety evaluation of the isolated LAB emphasized the benefits of Souro for further use in the human diet as well as the preparation of diverse probiotic food formulations.
\end{abstract}

Keywords: Probiotic bacteria, Lactobacillus, in-vitro evaluation, Souro, total protein and lipid

\section{INTRODUCTION}

The word "probiotic" is taken from Greek word meaning for life. This term was initiated used by Lilly and Stillwell in 1965 to explain the materials secreted by a microorganism which arouses the growth of other microorganisms, and thus contrasts with the term antibiotics (Lilly et al., 1965). The definition presented below is the closest definition to the full definition of probiotics by Havenaar et al. (Havenaar et al., 1992). The product contains microorganisms which contain certain viable microorganisms in sufficient numbers altering the microbial flora through replacement with colonization in the host body and thereby exerting beneficial effects on the host's health. Probiotics are generally considered as safe (GRAS) for human and as they are non-pathogenic bacteria (Davani-Davari et al. 2019; Mohkam et al., 2019). The selection of probiotic species is based largely on their historical use for a long time without any injurious side effects. Practically, probiotic food and drug products have to last for a long time, they should contain a large number of living cells, and they should non-pathogenic and non-toxic (Campieri et al., 2001).

Lactobacillus have different species, which are present as normal flora in the digestive tract and genitourinary tract (Montazeri-Najafabady et al., 2018). A Russian scientist, Henberg, proposed the production of reform yoghurt from intestinal L. acidophilus; then this yoghurt was produced in Germany in the 1980s as Mild Yogurt (Heller, 2001). Yogurt is a prominent example of probiotic foods which are highly regarded worldwide and the main probiotic bacteria of yogurt are Bifidobactoria and Lactobacillus. There are also probiotic milk, cheese, ice cream and other useful foods and products. Lactobacilli are beneficial for most people, including infants and children as well as useful for women with vaginal problems; however, they may have mild side effects, including gastrointestinal bloating and gas (Saavedra, 2001).

There are various Iranian fermented foods including Tarkhineh or Tarhana which is widely used in west of Iran. This food produced from fermentation of chapped wheat, vegetables and yogurt, simultaneously (Joghataei et al., 2019). Lighvan cheese is a well-known traditional Iranian native cheese, with a long track record of safety. It is fabricated from sheep milk without any heating process or adding starter included in its production steps. Its natural microbial flora made up of intrinsic lactic acid bacteria that have unique properties (Hanifian, 2020).

In Southern Iran, there is a regional fermented product called Mahwah, Mahyawah or Moh. The term "Mahwah" or "Mahyawah" is originally from two words, "fish" and "water" (Zarei et al., 2012). Another product, Souro or Souri, is produced in southern Iran, particularly in Boushehr and Lamerd, which is slightly different from Mahyawah. Souro is a very nutritious food containing phosphorus as well as rich in protein (more than $45 \%$ ) and valuable lipid content including omega-3 and omega-6. There are some reports (nonofficial) that local people using Souro, had no gastrointestinal problems according to other parts of Iran. In the Southern Iran, Souro means "salty", which issued as seasoning for other foods such as Gebneh "Khamir" is a bread made from Souri, egg, turmeric, and sesame with wheat flour in furnace with firewood. As noted, there is no report on probiotic content of Souro. For the first time, we aim to examine the nutritional value of Souro by determining the overall lipid and protein content and its basic elements, as well as exploring probiotic bacteria in this product. With regard to probiotics as well as their nutritional benefits, it can be concluded that these microorganisms can take part in a significant role in providing public health and diminishing the risk of numerous disorders, particularly gastrointestinal diseases.

\section{MATERIAL AND METHODS}

\section{Food sampling}

First, a total of 35 samples of the traditional Souro product were collected separately from the north regions of Persian Gulf including Narman and Lamardas well as Boushehr. These samples were carefully obtained from products of which production date was not over 4 months. The samples were maintained in a sterile container and transferred to analytical laboratory. Then, the samples were immediately used for microbial and biochemical experiments. Otherwise, they stored at $4^{\circ} \mathrm{C}$ just for 30 days for further experiments.

For isolation of probiotic strains, Man Rogosa Sharpe broth (MRS) medium was chosen (Ebrahimi et al., 2016). In this regards, One milliliter of every food sample was homogenized with $9 \mathrm{~mL}$ of distilled Buffered Phosphate Saline (PBS) and mixed comprehensively for one minute. Serial dilutions were prepared and $100 \mu \mathrm{L}$ of every dilution were cultured on MRS agar followed by incubation under anaerobic conditions at $37{ }^{\circ} \mathrm{C}$ for 48 hours. Then, the gram positive bacilli and negative catalase producer bacteria were selected for further evaluations. 


\section{Total Lipid Content Measuremen}

\section{Lipid extraction}

A chemical extraction was performed to measure total lipid content of the fermented Souro (Chyne et al., 2019). In this regards, a total of $5 \mathrm{~g}$ of each Souro sample was taken and centrifuged at $4000 \mathrm{rpm}$ for $10 \mathrm{~min}$. The sediment was discarded and the remaining supernatant was stored at $-70^{\circ} \mathrm{C}$ for $24 \mathrm{~h}$, then, freeze dried to form a dry brown powder. The lipid extraction was done by adding 200 $\mathrm{mg}$ dried powder of each lyophilized sample into $5 \mathrm{ml}$ mixture of chloroform:methanol (1:2) and sonicated for about 30 s followed by centrifuging at $3000 \mathrm{rpm}$ for 5 minutes. The supernatants were gathered and dried at $50{ }^{\circ} \mathrm{C}$.

\section{Lipid Quantitation}

The colorimetric sulfo-phospho-vanillin (SPV) method was used to evaluate tota lipid (Cheng et al., 2011). For this purpose, defined aliquots of standard lipids (olive oil) or meibum were dried by evaporation followed by incubation with 95 $\%$ sulfuric acid $(120 \mu \mathrm{l})$ at $95{ }^{\circ} \mathrm{C}$ for 20 minutes in distinct glass tubes. Afterward, the reaction blends were swiftly chilled by putting the tube on an ice tray, along with vortexing. Then, $100-\mu 1$ of each blend was placed to wells of a 96-well microplate. Preliminary measurement of pre-vanillin absorbance was performed by a Beckman Coulter DTX880 Multimode Detector (Beckman Coulter, Indianapolis, IN, USA) by means of a 535-nm filter via adding of $50 \mu$ l of 0.2 $\mathrm{mg} / \mathrm{ml}$ vanillin in $17 \%$ aqueous phosphoric acid along with by incubation at ambient temperature for 10 minutes in the dark location and inscribing of a postvanillin absorbance at the similar wavelength $\left(A_{535}\right)$. The ultimate samples' SPV response was described as the discrepancy among the final post-vanillin and prevanillin at $535 \mathrm{~nm}$ absorbance.

\section{Total Protein Content Measurement}

To evaluate total protein content of all specimens of Souro, the total protein assay was performed using available commercial kit (Pars Azmoon Co., Iran) in accordance with the manufacturer's instructions, which was on the basis on the Biuret method (Liu et al., 2017).

\section{Elemental Analysis}

The elemental combustion system was used by combination of two gas chromatography and combustion techniques in order to investigating the element content in the fermented Souro.

\section{Identification of microorganisms}

The physiological, morphological, and biochemical characterizations of the probiotic isolates were determined by identification tests. For additional recognition, the analysis of $16 \mathrm{~S}$ rRNA gene sequence was fulfilled in accord with Mohkam et al. (Mohkam et al., 2016a). In brief: one $1 \mathrm{~mL}$ of each bacterial culture (in middle to late exponential phase) was gathered by centrifugation (13000 $\mathrm{g}$ for 3 minutes at ambient temperature) in a sterilized $1.5 \mathrm{~mL}$ microfuge tube. The precipitated cells were suspended again in $0.5 \mathrm{~mL}$ of PBS buffer. The blend was agitated followed by genomic DNA extraction using heat shock approach for using in PCR extension of $16 \mathrm{~S}$ rRNA gene. The $1 \%(\mathrm{w} / \mathrm{v})$ agarose gel of amplified DNA samples were conducted using TBE electrophoresis buffer comprising of $1 \mu \mathrm{g} / \mathrm{mL}$ ethidium bromide followed by photographing of gel under UV light. The primer pair (Forward and Reverse) utilized for bacterial 16S rRNA gene amplification were: The general prokaryotic 5'-CAGCCGCGGTAATAC-3'as forward primer and 5'-ACGGGCGGTGTGTAC-3' as reverse primer (provided by Aran Sanat Yekta, Tehran, Iran), which extent a 800-bp area of the 16S rRNA gene. PCR reaction was conducted as follows (total volume of $50 \mu \mathrm{L}$ ): $5 \mu \mathrm{L}$ of sample chromosomal DNA and $2 \mu \mathrm{L}$ of both primers along with $25 \mu \mathrm{L}$ of Master Mix (Pars Tous, Iran). Then after, purification was done for PCR products followed by sequencing (CinnaGen, Tehran, Iran). The obtaining 16S rRNA gene sequences were blasted to the nucleotide sequences of identified bacteria in GenBank database of the National Center for Biotechnology Information by using Basic Local Alignment Search Tool (BLAST).

\section{Evaluating Probiotic Potential of Microorganisms}

\section{Acid and bile salt tolerance}

The stamina of isolated bacteria to acid and bile salts were assayed consistent with Duc et al. 2004, with a little alterations (Mohkam et al., 2016b). Briefly, MRS broth with $\mathrm{pH} 2.5$ was set up and inoculated by bacterial cell suspension of each the isolate. $0.5 \mathrm{ml}$ of each sample was investigated at 0 and $3 \mathrm{~h}$ for total viable cell count. For enumeration of bacterial cells, a $100 \mu \mathrm{L}$ of each sample was plated on MRS agar and incubated at $37^{\circ} \mathrm{C}$ for $18 \mathrm{~h}$ at $\mathrm{pH} 6.5$.

For bile salt tolerance, MRS agar containing $0.5 \%$ Oxgall was prepared and streaked with one colony of each isolates and incubated at $37^{\circ} \mathrm{C}$ for $24 \mathrm{~h}$. Aliquots
$(100 \mu \mathrm{L})$ were picked out at 1 and $3 \mathrm{~h}$ intervals. Suitable dilutions of each sample were cultured directly on nutrient agar plates followed by incubation at $37^{\circ} \mathrm{C}$ for $24 \mathrm{~h}$ for enumeration of Colony Forming Unit (CFU) (Mohkam et al., 2016b).

\section{Antibiotic susceptibility examination}

The vulnerability of the bacterial isolates (adopted from the Clinical and Laboratory Standards Institute 2007) to ciprofloxacin, ampicillin, penicillin G, chloramphenicol, gentamicin, cefalexin, cephalothin, erythromycin and sulfamethoxazol were determined using Muller-Hinton agar (Himedia, India) using disk diffusion assay (Mohkam et al., 2016b).

\section{Protease and amylase assay}

The isolated bacteria were monitored for protease fabrication using plate assay method in accordance with Mohkam et al (Mohkam et al., 2016b). Protease production medium was contained casein $1 \%$ and skim milk $1 \%$. Plates were spo inoculated with the isolates culture and incubated at $37{ }^{\circ} \mathrm{C}$ for $24 \mathrm{~h}$. After incubation, the plates were submerged with trichloroacetic acid (TCA) $2.5 \%$ for $10 \mathrm{~min}$. The clear zone around colonies was recognized as positive strain for protease production.

For amylase assay, the MRS agar supplemented with $1 \%$ soluble starch were spot inoculated with the isolates culture and incubated at $37^{\circ} \mathrm{C}$ for $24 \mathrm{~h}$. Afterward, the plates were swamped with lugol solution. The appearance clear zone nearby colonies was recognized as positive strain for amylase production.

\section{Cell surface hydrophobicity test}

Cell surface hydrophobicity assay or Microbial Adhesion to Hydrocarbon (MATH Assay) was done as stated by Mohkam et al method (Mohkam et al., 2016b). Briefly, the centrifuging was done for the overnight grown culture at $8000 \mathrm{rpm}$ for $15 \mathrm{~min}$ followed by the pellet washing with phosphate-buffered saline (PBS, pH 7.2) and then resuspension in the equal buffer to an absorbance $\left(\mathrm{A}_{600} \mathrm{~nm}\right)$ of 1.2 1.6. One $\mathrm{ml}$ of each sample was added to obtain an equal amount of solvent xylene (an apolar solvent) and chloroform (a monopolar and acidic solvent) and thoroughly mixed with vortexing for $2 \mathrm{~min}$, followed by incubation at $30{ }^{\circ} \mathrm{C}$ for 10 $\mathrm{min}$ and then robustly remixed again for an additional $2 \mathrm{~min}$. The aqueous phase absorbent was dignified at $600 \mathrm{~nm}$ after staying at room temperature for $20 \mathrm{~min}$. The hydrophobicity of isolate sticking to solvent was computed as:

$\%$ Hydrophobicity $=\left[\left(\mathrm{A}_{0}-\mathrm{A}\right) / \mathrm{A}_{0}\right] \times 100$

where $\mathrm{A}_{0}$ and $\mathrm{A}$ are absorbance $\left(\mathrm{A}_{600}\right)$ before and after extraction with organic solvents, respectively.

\section{Auto-aggregation assay}

Auto-aggregation assay was done as stated by Mohkam et al. . Isolate was grown over night in MRS broth at $37{ }^{\circ} \mathrm{C}$. The bacterial cells were pelleted via centrifugation for $15 \mathrm{~min}$ at $8000 \mathrm{rpm}$ and rinsed two times with PBS (pH 7.3) then suspended again in PBS buffer to reach $\mathrm{A}_{600}$ to 0.5 of which $4 \mathrm{ml}$ was blended by mild vortexing for 10 seconds followed by incubation at $37{ }^{\circ} \mathrm{C}$ for $1 \mathrm{~h}$. The absorbance of superior suspension was gauged after incubation. Auto-aggregation percentage was presented as:

Auto-aggregation $\%=\mathrm{A}_{0}-\left(\mathrm{A} / \mathrm{A}_{0}\right) \times 100$

where $\mathrm{A}$ showed the absorbance at time $\mathrm{t}=1 \mathrm{~h}$ and $\mathrm{A}_{0}$ the absorbance at $\mathrm{t}=0 \mathrm{~h}$

\section{Statistical analysis}

The experiments were evaluated three times and values are showed as mean $\pm \mathrm{SD}$. The one-way Analysis of Variance (ANOVA) was used for noteworthy differences among the mean values of each sample. Finally, the Duncan's multiple range test (DMRT) was performed by means of SPSS version 19.0. A value of $\mathrm{P}<0.05$ was considered significant.

\section{RESULTS}

\section{Total Lipids and Total Protein}

\section{Total lipid content}

Total lipid content in the specimens was obtained by comparison to olive oil as standard oil in percentage of primary dry weight, as shown in Table 1 . The results depicted that average total lipid content was $11.18 \pm 0.38 \%$ in all three specimens (A, B, C). 
Table 1 Total protein and total lipid content in Souro specimens

\begin{tabular}{|c|c|c|}
\hline Specimen & $\begin{array}{l}\text { Total lipid content in } \\
\text { Souro }\end{array}$ & Total protein content in Souro \\
\hline 1 & $11.70 \% \pm 0.09$ & $43 \% \pm 1.20$ \\
\hline 2 & $11.05 \% \pm 0.08$ & $38 \% \pm 1.11$ \\
\hline 3 & $10.80 \% \pm 0.09$ & $74 \% \pm 2.33$ \\
\hline 4 & $10.37 \% \pm 0.07$ & $51 \% \pm 1.95$ \\
\hline 5 & $11.75 \% \pm 0.08$ & $41 \% \pm 1.32$ \\
\hline 6 & $12.09 \% \pm 0.09$ & $42 \% \pm 1.38$ \\
\hline 7 & $10.01 \% \pm 0.06$ & $71 \% \pm 2.65$ \\
\hline 8 & $9.08 \% \pm 0.06$ & $50 \% \pm 1.89$ \\
\hline 9 & $10.03 \% \pm 0.07$ & $44 \% \pm 1.42$ \\
\hline 10 & $11.75 \% \pm 0.09$ & $42 \% \pm 1.39$ \\
\hline 11 & $12.55 \% \pm 0.10$ & $51 \% \pm 1.94$ \\
\hline 12 & $13.92 \% \pm 0.13$ & $51 \% \pm 1.91$ \\
\hline 13 & $13.08 \% \pm 0.12$ & $69 \% \pm 2.15$ \\
\hline 14 & $9.08 \% \pm 0.07$ & $71 \% \pm 2.36$ \\
\hline 15 & $9.11 \% \pm 0.08$ & $53 \% \pm 1.41$ \\
\hline 16 & $12.45 \% \pm 0.11$ & $42 \% \pm 1.31$ \\
\hline 17 & $13.09 \% \pm 0.13$ & $49 \% \pm 1.74$ \\
\hline 18 & $10.33 \% \pm 0.09$ & $63 \% \pm 2.15$ \\
\hline 19 & $10.97 \% \pm 0.08$ & $57 \% \pm 1.91$ \\
\hline 20 & $12.11 \% \pm 0.11$ & $46 \% \pm 1.82$ \\
\hline 21 & $11.77 \% \pm 0.09$ & $55 \% \pm 1.86$ \\
\hline 22 & $12.82 \% \pm 0.09$ & $48 \% \pm 1.73$ \\
\hline 23 & $11.50 \% \pm 0.08$ & $74 \% \pm 2.58$ \\
\hline 24 & $12.09 \% \pm 0.11$ & $70 \% \pm 2.39$ \\
\hline 25 & $12.71 \% \pm 0.12$ & $39 \% \pm 1.21$ \\
\hline 26 & $11.75 \% \pm 0.09$ & $38 \% \pm 1.26$ \\
\hline 27 & $9.43 \% \pm 0.06$ & $47 \% \pm 1.76$ \\
\hline 28 & $9.02 \% \pm 0.05$ & $43 \% \pm 1.50$ \\
\hline 29 & $10.95 \% \pm 0.08$ & $59 \% \pm 1.67$ \\
\hline 30 & $10.01 \% \pm 0.07$ & $69 \% \pm 2.24$ \\
\hline 31 & $9.05 \% \pm 0.06$ & $40 \% \pm 1.31$ \\
\hline 32 & $11.27 \% \pm 0.08$ & $39 \% \pm 1.20$ \\
\hline 33 & $12.01 \% \pm 0.10$ & $41 \% \pm 1.42$ \\
\hline 34 & $10.77 \% \pm 0.07$ & $42 \% \pm 1.35$ \\
\hline 35 & $10.99 \% \pm 0.07$ & $38 \% \pm 1.29$ \\
\hline
\end{tabular}

Legend: values are showed as mean \pm SD

\section{Total protein content}

The result of total protein content in the specimens is given in Table 1. The findings provided that total protein content in Souro was $51 \pm 0.16 \%$, on average.

\section{Results of Elemental Analysis of Souro}

The elemental combustion analysis showed the percentages of hydrogen, carbon, nitrogen and sulphur in the specimens (Table 2).As shown in Table 2, carbon, nitrogen, hydrogen and sulphur content account approximately for $40 \%, 9 \% .5 \%$ and 3\% of total elements existed in the product, respectively.

Table 2 The results of elemental analysis of Souro

\begin{tabular}{ll}
\hline Basic elements & Weighted percentage (on average) \\
\hline Carbon & $39.08 \pm 0.81 \%$ \\
\hline Hydrogen & $5.39 \pm 0.13 \%$ \\
\hline Nitrogen & $8.82 \pm 0.45 \%$ \\
\hline Sulphur & $2.94 \pm 0.73 \%$ \\
\hline
\end{tabular}

Table 5 Sensitivity of the Bacillus isolates to several antibiotics

\begin{tabular}{|c|c|c|c|c|c|c|c|c|c|}
\hline Bacteria & $\begin{array}{c}\text { Ampicilli } \\
\mathrm{n}\end{array}$ & $\begin{array}{c}\text { Penicilli } \\
n\end{array}$ & $\begin{array}{c}\text { Cefalexi } \\
n\end{array}$ & $\begin{array}{c}\text { Sulfamethoxazol } \\
\mathrm{e}\end{array}$ & $\begin{array}{c}\text { Erythromyci } \\
\mathrm{n}\end{array}$ & $\begin{array}{c}\text { Cephalothin } \\
\mathrm{e}\end{array}$ & $\begin{array}{c}\text { Ciprofloxaci } \\
n\end{array}$ & $\begin{array}{c}\text { Gentamici } \\
n\end{array}$ & $\begin{array}{c}\text { Chloramphenico } \\
1 \\
\end{array}$ \\
\hline L.hilgardii & $\mathrm{S}$ & $\mathrm{R}$ & $\mathrm{S}$ & $\mathrm{R}$ & $\mathrm{S}$ & $\mathrm{S}$ & $S$ & $\mathrm{~S}$ & $\mathrm{~S}$ \\
\hline L. fermentum & $\mathrm{S}$ & $\mathrm{R}$ & $\mathrm{S}$ & $\mathrm{R}$ & $S$ & $\mathrm{~S}$ & $\mathrm{~S}$ & $\mathrm{~S}$ & $\mathrm{~S}$ \\
\hline L. plantarum & S & S & S & S & $\mathrm{S}$ & S & S & S & S \\
\hline $\begin{array}{l}W . \\
\text { paramesenteroide } \\
s\end{array}$ & S & $\mathrm{R}$ & S & $\mathrm{R}$ & S & $\mathrm{R}$ & S & $\mathrm{R}$ & $\mathrm{R}$ \\
\hline L. casei & $\mathrm{R}$ & $\mathrm{R}$ & $\mathrm{R}$ & $\mathrm{S}$ & $\mathrm{S}$ & $\mathrm{S}$ & $\mathrm{R}$ & $\mathrm{R}$ & $\mathrm{R}$ \\
\hline
\end{tabular}

Legend: Resistance (R): $0-5 \mathrm{~mm}$; Sensitive (S):>10 mm

\section{Amylase and protease assay}

Beneficial enzymes including amylase and protease were evaluated. In this regard, all isolates were able to produce amylase; however, only L. Plantarum, L. Hilgardi and $L$. casei had the ability to hydrolyze the protein.
Legend: values are showed as mean $\pm \mathrm{SD}$

\section{Screening and identification of isolates}

Various gram positive bacilli as well as negative catalase activity were isolated. By applying various morphological and biochemical tests (data not shown), 5 isolates were opted due to the high diversity of morphology and biochemical variables (C, E, G, K and J). Finally, a PCR method based on universal 16rdDNA primer was applied in order to better identification of bacteria. The existence of a band of $800 \mathrm{bp}$ was appeared for $16 \mathrm{~s}$ rDNA amplified sequence. Finally, according to the BLAST analysis of 16s rDNA sequences, various Lactobacilli as well as Weissella spp. were identified (Table 3).

Table 3 Five final samples isolated from specimens of Souro

\begin{tabular}{lc}
\hline Isolate code & Species \\
\hline $\mathrm{G}$ & L. plantarum \\
\hline $\mathrm{C}$ & L. hilgardii \\
\hline $\mathrm{E}$ & L. fermentum \\
\hline $\mathrm{J}$ & L. casei \\
\hline $\mathrm{K}$ & W. \\
\end{tabular}

\section{In vitro assessment of probiotic potentials}

\section{Acid tolerance assay}

The rates of low $\mathrm{pH}$ value tolerance of the five isolates were somehow similar among the tested bacterial isolates. As shown in Table 4, there is higher than $80 \%$ of survival in MRS broth at $\mathrm{pH} 2.5$ after $3 \mathrm{~h}$. Isolates $\mathrm{E}$ and $\mathrm{G}$ were the most acidtolerant strains with survivability of more than $90 \%$. More interestingly, isolate $\mathrm{E}$ could grow even in acidic condition. The results indicated that these five isolates could tolerate acidic conditions.

\begin{tabular}{|c|c|c|c|c|c|}
\hline \multirow{3}{*}{$\begin{array}{l}\text { Bacterial } \\
\text { isolate }\end{array}$} & \multirow{2}{*}{\multicolumn{2}{|c|}{$\begin{array}{c}\text { Acid tolerance } \\
\log _{10} \mathrm{CFU} \text { of viable bacteria } \\
\text { per ml }\end{array}$}} & \multirow{3}{*}{$\begin{array}{l}\text { Survival } \\
\text { after } 3 \mathrm{~h} \\
(\%)\end{array}$} & \multirow{2}{*}{\multicolumn{2}{|c|}{$\begin{array}{c}\text { Bile salts tolerance } \\
\text { Percentage of } \\
\text { Survival }(\%)\end{array}$}} \\
\hline & & & & & \\
\hline & $0 \mathrm{~h}$ & $3 \mathrm{~h}$ & & $1 \mathrm{~h}$ & $3 \mathrm{~h}$ \\
\hline $\bar{C}$ & $5.79 \pm 0.15$ & $5.10 \pm 0.18$ & 88.08 & 75 & 70 \\
\hline E & $5.58 \pm 0.12$ & $5.94 \pm 0.16$ & 100.06 & 92 & 85 \\
\hline G & $6.45 \pm 0.14$ & $5.85 \pm 0.19$ & 90.69 & 93 & 82 \\
\hline $\mathrm{J}$ & $5.90 \pm 0.12$ & $5.05 \pm 0.11$ & 85.59 & 81 & 76 \\
\hline K & $6.44 \pm 0.15$ & $5.17 \pm 0.13$ & 80.28 & 84 & 78 \\
\hline
\end{tabular}

\section{Bile salts resistance assay}

All the tested isolates depicted excellent persistance to bile salt (Oxgall) which ranged from 75 to $93 \%$ in $0.5 \%$ of Oxgall (Table 4). Strains E and G showed the highest survivability of $93 \%$ and $92 \%$, respectively following by isolates $\mathrm{K}$ and $\mathrm{J}$. Finally, isolate $\mathrm{C}$ had the lowest resistance to bile salts.

\section{Pattern of antibiotic susceptibility}

This test was performed to make certain that a potential probiotic strain did not have a movable genetic element accountable for antibiotic resistance determinants. Consequently, the selected bacterial isolates were incorporated to antibiotic susceptibility assessment. It was disclosed that all isolates were susceptible to Erythromycin and Ciprofloxacin and Cefalexin came after except for $L$. casei. In contrast, all bacteria except $L$. plantarum were resistant to penicillin (Table 5). 
aggregation activity (83\%) while strain L. fermentum had the lowest autoaggregation activity $(3 \%)$.

Table 6 Hydrophobicity percentage of the isolates to various solvents and autoaggregation

\begin{tabular}{lccc}
\hline Bacteria & $\begin{array}{c}\text { Adhesion to } \\
\text { chloroform }\end{array}$ & $\begin{array}{c}\text { Adhesion to } \\
\text { Xylene }\end{array}$ & $\begin{array}{c}\text { Auto- } \\
\text { aggregation }\end{array}$ \\
\hline $\begin{array}{l}\text { L.hilgardii } \\
\text { L. fermentum }\end{array}$ & $47 \% \pm 1.36$ & $93 \% \pm 3.19$ & $44 \% \pm 1.59$ \\
L. plantarum & $33 \% \pm 1.21$ & $39 \% \pm 1.23$ & $3 \% \pm 0.02$ \\
W. & $83 \% \pm 3.14$ & $57 \% \pm 1.44$ & $83 \% \pm 1.98$ \\
paramesenteroides & $52 \% \pm 1.56$ & $21 \% \pm 1.25$ & $39 \% \pm 1.14$ \\
L. casei & $29 \% \pm 1.12$ & $29 \% \pm 1.29$ & $18 \% \pm 1.11$ \\
\hline
\end{tabular}

Legend: values are showed as mean \pm SD

\section{DISCUSSION}

The traditional food system has attracted significant interest in modern era as it can attend as a chief supplier to food nutrition, security and wellbeing. Conventiona foods are belonged to easily available by Native Individuals from their vernacular and natural circumstances, via their conventional knowledge of gathering, hunting, farming and harvesting (Kuhnlein et al., 2009). In this regard, the importance of native foodstuffs as high-quality supply of nutrients including vitamins and minerals were reported in numerous researches providing that they are also comparable or indeed more superior than to the regularly devoured cultivars (Ghosh-Jerath et al., 2015; Saha et al., 2014). Hence, it is essential to register information relating to the native foodstuffs from relevant countries to enhance the health and nutritional situation of nutritionally susceptible populace.

Many traditional foodstuffs have been recognized but there is not enough information on their dietetic use, chemical ingredient and more interesting probiotic composition, which limit the perspective for their application. In this regard, determining the nutritional value as well as probiotic profile of Indigenous foodstuffs including Souro, could be extremely beneficial to nutritionally minor populations or to particular susceptible groups inside populations.

In this study, we collected several Souro samples from south of Iran (Boushehr and Lamerd). Initial nutritional analysis showed that this food had an average lipid content of $11.18 \%$, however, the protein content is varied from $38 \%$ till $74 \%$. This high variation in protein content might be related to type of fish or the preparation procedure. By considering the preparation process of Souro, this food contain about $12.5 \%$ of salt that seems to be a constraint for people with cardiovascular problems. On the one hand, this product has a high nitrogen content, which may endanger human health. Part of this nitrogen is likely to be converted to biogenic amines by the microorganisms (Zarei et al., 2012). It was reported that Mahyawah, another tradition food, which is somehow similar to Souro, had relatively high content of histamine (limit suggestion of $50 \mathrm{mg} / \mathrm{kg}$ by FDA) and then the minority of other biogenic amines. In this regard, high consumption of biogenic amines may cause scombroid poisoning. However, due to the salty tastes of this food, the usua intake of Souro is low, therefore, the intoxication will not occur. On the other hand, oral administration of biogenic amines do not usually incite detrimental reactions, because the intestine amine oxidases in gut quickly detoxify these compounds (Lüthy et al., 1983). In comparison to other fermented fish products including Geotgal, the traditional fermented fish, there is a high protein content (up to about 70\%) in Souro than geotgal (about 30\%) (Koo et al., 2016). Moreover, there are some Indian fermented fish named Hentak, Ngari and Tungtap which their protein contents are $32.7 \%, 34.1 \%$ and $32.0 \%$, respectively (Thapa, 2016).

In accordance with the World Health Organization guideline probiotics to be used as food or drug supplements should meet various qualifications. These requirements comprise of endurance via gastrointestinal tract (Maruo et al., 2006), resistance to gastric juice acid and physiological bile salt concentrations, being able to adhere to bowel epithelial cells (Schillinger et al., 2005), sensitivity to antibiotics (Anadon et al., 2006) and co-aggregation to form a barrier which hampers colonization by pathogens (Dunne et al., 2001). Above mentioned parameters are helpful for monitoring and choosing probiotic bacteria for additional in-vivo clinical trials as well as evaluating their safety and finally for application in humans.

The findings showed that all five isolates could endure acidic circumstances. In case of probiotics, acid forbearance is one of the most vital criterion, which is expected to be haunted by any strain to include an effect in the host gastrointestinal tract (Salminen et al., 1996). Borichaet al. performed an acid-tolerance test in various Lactobacillus isolates which showed survivability between 80 to $87 \%$ (Boricha et al., 2019). In a similar study, Shokri et al. stated that three strains of Lactobacillus could tolerate acidic situations ( $\mathrm{pH} 2.5$ for $3 \mathrm{~h}$ ) with survivability of $76 \%$, whereas other isolates failed to survive (Shokri et al., 2018). Moreover, it was described that lenience to GIT transitional conditions is a strain specific feature (Campana et al., 2017). In this regard, L. acidophilus ATCC 4356 showed more than 4-log lost of its viability cycles which indicated had minimum resistance to simulated gastric juice that is in agreement with the outcomes of Ortakci and Sert (Ortakci et al., 2012). Conversely, Charteris et al. claimed that resistant to gastric juice in some L. fermentum strains are intrinsic (Charteris et al., 1998). In comparison to the above-mentioned reports, our results showed superior tolerance to acidic conditions. These findings revealed that Souro could be regarded as one of the most potent sources for investigating novel probiotic sources that can tolerate discordant conditions.

One of the most vital criterions for endurance and growth of probiotic bacteria in the bowel tract is resistance to bile salts. The unfavorable circumstances in the small bowel is that probiotics need to be survived in the existence of bile salts and pancreatin (Mohkam et al., 2016b). All isolates showed good resistance to bile salt (Oxgall) than low pH values, which is in agreement with the results of Lee et al (Lee et al., 2016). In addition, various researchers have reported that tolerance to bile salts is associated to bile salt hydrolysis (BSH) activity. In our study, the majority of the strains were not able to deconjugate bile salts, in contrast, being to survive as well. These findings are consistent with Moser and Savage claiming that bile salt resistance are not relevant to BSH activity (Moser et al., 2001). In another experiment, Borichaet al. reported that most of isolates were resistant to bile salt. A similar pattern was also observed for L. plantarum KJ722784 according to Angmoet al. study (Angmo et al., 2016). A $0.3 \%$ of bile salt concentration is regarded to be a vital concentration to assess a bile-resistant probiotic (Shokri et al., 2018). Thus, according to the current outcomes, all five strains, especially strain $\mathrm{G}$ (L. plantarum), showed outstanding bile salt tolerance for being regarded as potential probiotics.

The susceptibility to antibiotic is conducted to ensure that a potential probiotic strain did not have a movable genetic component accountable for antibiotic resistance determinants. Therefore, the selected isolates were incorporated to antibiotic susceptibility assessment. There was only Erythromycin that all isolates were susceptible to this antibiotic. On the other hand, most of isolates were resistant to penicillin. Resistance to penicillin and ampicillin might be attributed to modification of PBPs (penicillin binding proteins). Recent studies showed that these resistances to penicillin and ampicillin may be an intrinsic trait of Lactobacillus species (Shokri et al., 2018). Therefore, the intrinsic antibiotic resistance traits of probiotic isolates with could be beneficial for refurbishing the intestine microbiota after antibiotic usage. However, further investigations are required to elucidate this issue. Overall, pattern of susceptibly and intrinsic resistance of these isolates to the given antibiotics is important, especially when they are administrated at the time of antibiotic treatment for such diseases.

All Isolates were positive for producing amylase and only three isolates were capable to produce protease. These enzymes could be considered as an accessory enzymes for better digestion process in host gastrointestinal tract (Gholami $\boldsymbol{e t}$ al. 2016; Gholami et al., 2015). In a similar study, Tallapragada et al. (2018) isolated Lactobacillus spp. were able to produce amylase at industrial scale (Padmavathi et al., 2018). In another study, Taheri et al. (2009) isolated some Lactobacillus sp able to produce amylase as well as protease (Taheri $\boldsymbol{e t} \boldsymbol{a l . , 2 0 0 9 ) . ~ I t ~ i s ~ a l s o ~}$ proposed that proteases may assist to cleave the pathogen's receptor sites in intestinal epithelial cells (Rowan et al., 2001). Similarly, Saccharomyces boulardii as one of the commercially available probiotics is able to cleave the Clostridium difficile toxin A receptor sites from the superficial of gut epithelium cells which help to prevent recurrence of $C$. difficile infection (Patel et al., 2009).

There is a complex process for adhesion of bacteria comprising of contacting among both cell membrane of bacteria and interacting surfaces (A Abbaszadegan et al., 2016; Abbas Abbaszadegan et al., 2016a; Abbas Abbaszadegan et al. 2016b). Cell surface hydrophobicity is regarded as one of the chief features of bacteria. Regardless of a number of researches on the hydrophobicity of cell surface and charges of Lactobacillus spp., these physico-chemical features are not well understood. In the current research, MATH was applied to specify the characterization of cell surface and the potential capability of Lactobacillus strains to stick to a support. The findings relating to hydrophobicity of experiments utilized in this research provided alike trends with xylene indicating that this solvent can be employed in hydrophobicity assay. Most of the LAB isolates assessed in this study illustrated good hydrophobicity for Xylene (except for $W$ paramesenteroides) as well as for chloroform. Bacterial adhesion to xylene, an apolar solvent, imitates hydrophobicity of cell surface, while the adhesion to chloroform, is considered as a measure of electron donor (basic) features of the bacteria (Patel et al., 2009). As shown in Table 7, the majority of the isolates, especially L. hilgardii and L. plantarum showed good affinity to both xylene and chloroform, implying that they possessed hydrophobic cell surface as well as good hydrophilic surface which enable these bacteria for excellent adhesion to host gut. Bacterial adhesion reflects the ability of bacterial probiotics for colonization in the GIT which prevents access of pathogen by means of particular hindrance on receptor of cells or steric interactions (Patel et al., 2009). This characteristic also donates a competitive vantage for maintenance in human or animal GIT (Patel $\boldsymbol{e}$ al., 2009)

As for auto-aggregation, L. hilgardii and L. plantarum exhibited the highest autoaggregation activity (83\% and 44\%). Collado et al. (2007) suggested that aggregation is helpful for initial monitoring to recognize the potent probiotic strains appropriate for food, human, or animal use (Collado et al., 2007). Thus, the superior aggregation trait of $L$. hilgardii and $L$. plantarum represent their characteristic aspect for interaction with pathogens, which is of vital for food protection as well as the curative impact of nutrition on bowel microbiota. In almost all cases, aggregation is associated to attaining a sufficient mass to generate 
biofilm, sticking to the surface of mucosal GIT and consequently, maintaining in the host's GIT and exploiting their actions (Ferreira et al., 2011). In addition, it was reported that auto-aggregation is helpful for initial screening to recognize the powerful probiotic strains appropriate for individual or animal use (Mohkam $\boldsymbol{e}$ al., 2016b). Hence, the superior auto-aggregation trait of isolates L. hilgardii and L. plantarum showed their capabilities of interaction with pathogens which is important point in therapeutic influence on intestinal microbiota.

\section{CONCLUSION}

This study is a report on introduction, characterization and identification of microbial diversity in one of the traditional Iranian fermented food Souro. In terms of nutritional value, this product contains high amounts of protein as well as lipid and some basic elements necessary for the body; however, overconsumption need to be reviewed, particularly for cardiovascular patients. The results of this study indicate the presence of specific strains of Lactobacillus and Weissella. The lactobacillus genus is the dominant genus in all samples, which suggests that Souro can be regarded as a product including probiotic bacteria. On the other hand, bacteria can be isolated and used at the industrial level to produce probiotic therapeutic products. Probiotic effects of Souro appear to be due to the sum of microorganisms present in the product, which can be used as a probiotic product in terms of resistance to gastric acid and bile acid, intestinal adhesion and sufficient amount of hydrophobicity. By isolation of the microorganisms found in Souro, stable formulation of these probiotics can be used as probiotic drugs.

Acknowledgments: This study was supported by a Grant from the Research Council of Shiraz University of Medical Sciences, Shiraz University of Medical Sciences, Shiraz, Iran.

\section{REFERENCES}

Abbaszadegan, A., Dadolahi, S., Gholami, A., Moein, M., Hamedani, S., Ghasemi, Y., \& Abbott, P. (2016). Antimicrobial and cytotoxic activity of Cinnamomum zeylanicum, Calcium Hydroxide, and triple antibiotic paste as root canal dressing materials. J Contemp Dent Pract, 17(2), 105-113. https://doi.org/10.5005/jpjournals-10024-1811

Abbaszadegan, A., Gholami, A., Ghahramani, Y., Ghareghan, R., Ghareghan, M., Kazemi, A., . . . Ghasemi, Y. (2016a). Antimicrobial and cytotoxic activity of Cuminum cyminum as an intracanal medicament compared to chlorhexidine gel. Iran Endod J, 11(1), 44. http://dx.doi.org/doi:10.7508/iej.2016.01.009

Abbaszadegan, A., Sahebi, S., Gholami, A., Delroba, A., Kiani, A., Iraji, A., \& Abbott, P. V. (2016b). Time-dependent antibacterial effects of Aloe vera and Zataria multiflora plant essential oils compared to calcium hydroxide in teeth infected with Enterococcus faecalis. J Investig Clin Dent, 7(1), 93-101. http://dx.doi.org/doi:10.1111/jicd.12123

Anadon, A., Martinez-Larraaga, M. R., \& Martinez, M. A. (2006). Probiotics for animal nutrition in the European Union. Regulation and safety assessment. Regu Toxicol Pharm, 45(1), 91-95. http://dx.doi.org/doi:10.1016/j.yrtph.2006.02.004 Angmo, K., Kumari, A., \& Bhalla, T. C. (2016). Probiotic characterization of lactic acid bacteria isolated from fermented foods and beverage of Ladakh. LWT Food Sci Technol, 66, 428-435. http://dx.doi.org/doi:10.1016/j.lwt.2015.10.057

Boricha, A. A., Shekh, S. L., Pithva, S. P., Ambalam, P. S., \& Vyas, B. R. M. (2019). In vitro evaluation of probiotic properties of Lactobacillus species of food and human origin. LWT Food Sci Technol, 106, 201-208 http://dx.doi.org/doi:10.1016/j.1wt.2019.02.021

Campana, R., van Hemert, S., \& Baffone, W. (2017). Strain-specific probiotic properties of lactic acid bacteria and their interference with human intestinal pathogens invasion. Gut Pathog, 9(1), 1-12. https://doi.org/10.1186/s13099-0170162-4

Campieri, M., \& Gionchetti, P. (2001). Bacteria as the cause of ulcerative colitis. Gut, 48(1), 132-135. https://doi.org/doi:10.1136/gut.48.1.132

Charteris, W., Kelly, P., Morelli, L., \& Collins, J. (1998). Development and application of an in vitro methodology to determine the transit tolerance of potentially probiotic Lactobacillus and Bifidobacterium species in the upper human gastrointestinal tract. $J$ Appl Microbiol, 84(5), 759-768. https://doi.org/10.1046/j.1365-2672.1998.00407.x

Cheng, Y. S., Zheng, Y., \& VanderGheynst, J. S. (2011). Rapid quantitative analysis of lipids using a colorimetric method in a microplate format. Lipids, 46(1), 95-103. http://dx.doi.org/doi:10.1007/s11745-010-3494-0

Chyne, D. A. L., Ananthan, R., \& Longvah, T. (2019). Food compositional analysis of Indigenous foods consumed by the Khasi of Meghalaya, North-east India. $J$ Food Compost Anal, 77, 91-100. http://dx.doi.org/doi:10.1016/j.jfca.2019.01.008 Collado, M. C., Grześkowiak, Ł., \& Salminen, S. (2007). Probiotic strains and their combination inhibit in vitro adhesion of pathogens to pig intestinal mucosa. Curr Microbiol, 55(3), 260-265. http://dx.doi.org/doi:10.1007/s00284-007-0144-8

Davani-Davari, D., Negahdaripour, M., Karimzadeh, I., Seifan, M., Mohkam, M., Masoumi, S. J., . . . Ghasemi, Y. (2019). Prebiotics: definition, types, sources, mechanisms, and clinical applications. Foods, 8(3), 92 http://dx.doi.org/doi:10.3390/foods8030092
Dunne, C., O'Mahony, L., Murphy, L., Thornton, G., Morrissey, D., O'Halloran, S., . . . Daly, C. (2001). In vitro selection criteria for probiotic bacteria of human origin: correlation with in vivo findings. Am J Clin Nutr, 73(2), 386s-392s. http://dx.doi.org/doi:10.1093/ajcn/73.2.386s

Ebrahimi, N., Gharibi, S., Ghoshoon, M. B., Karimi, Z., Gholami, A., Nezafat, N., Ghasemi, Y. (2016). Selective Isolation and Identification of Arginine Degrading Bacteria; the Optimized Arginine Deaminase Production by Enterobacter sp. sgn1 as a New Source of This Potentially Anti-Tumor Enzyme. $J$ Appl Pharm Sci, 6(09), 093-101. http://dx.doi.org/doi:10.7324/JAPS.2016.60914 Ferreira, C. L., GRZEŚKOWIAK, Ł., Collado, M. C., \& Salminen, S. (2011). In vitro evaluation of Lactobacillus gasseri strains of infant origin on adhesion and aggregation of specific pathogens. $J$ Food Prot, 74(9), 1482-1487. https://doi.org/10.4315/0362-028x.jfp-11-074

Gholami, A., Mohkam, M., Rasoul-Amini, S., \& Ghasemi, Y. (2016). Industrial production of polyhydroxyalkanoates by bacteria: opportunities and challenges. Minerva Biotecnol, 28(1), 59-74

Gholami, A., Shahin, S., Mohkam, M., Nezafat, N., \& Ghasemi, Y. (2015). Cloning, characterization and bioinformatics analysis of novel cytosine deaminase from Escherichia coli AGH09. Int J Pept Res Ther, 21(3), 365-374. http://dx.doi.org/doi:10.1007/s10989-015-9465-9

Ghosh-Jerath, S., Singh, A., Kamboj, P., Goldberg, G., \& Magsumbol, M. S. (2015). Traditional knowledge and nutritive value of indigenous foods in the oraon tribal community of Jharkhand: an exploratory cross-sectional study. Ecol Food Nutr, 54(5), 493-519. http://dx.doi.org/doi:10.1080/03670244.2015.1017758

Hanifian, S. (2020). Behavior of Mycobacterium avium paratuberculosis in Lighvan cheese tracked by propidium monoazide qPCR and culture. $L W T, 133$, 109886. https://doi.org/10.1016/j.lwt.2020.109886

Havenaar, R., Ten Brink, B., \& Huis, J. H. (1992). Selection of strains for probiotic use Probiotics (pp. 209-224): Springer. https://doi.org/10.1007/978-94-011-2364 89

Heller, K. J. (2001). Probiotic bacteria in fermented foods: product characteristics and starter organisms. Am J Clin Nutr, 73(2), 374s-379s. http://dx.doi.org/doi:10.1093/ajcn/73.2.374s

Joghataei, M., Shahidi, F., Pouladfar, G., Mortazavi, S. A., \& Ghaderi, A. (2019) Probiotic potential comparison of Lactobacillus strains isolated from Iranian traditional food products and human feces with standard probiotic strains. J Sci Food Agr, 99(15), 6680-6688. https://doi.org/10.1002/jsfa.9945

Koo, O. K., Lee, S. J., Chung, K. R., Jang, D. J., Yang, H. J., \& Kwon, D. Y. (2016). Korean traditional fermented fish products: jeotgal. J Ethn Foods, 3(2), 107-116. https://doi.org/10.1016/j.jef.2016.06.004

Kuhnlein, H. V., Erasmus, B., \& Spigelski, D. (2009). Indigenous peoples' food systems: the many dimensions of culture, diversity and environment for nutrition and health: Food and Agriculture Organization of the United Nations Rome, Italy Lee, K. W., Shim, J. M., Park, S.-K., Heo, H.-J., Kim, H.-J., Ham, K.-S., \& Kim, J. H. (2016). Isolation of lactic acid bacteria with probiotic potentials from kimchi, traditional Korean fermented vegetable. LWT - Food Sci Technol, 71, 130-137. https://doi.org/10.1016/j.lwt.2016.03.029

Lilly, D. M., \& Stillwell, R. H. (1965). Probiotics: growth-promoting factor produced by microorganisms. Science, 147(3659), 747-748 http://dx.doi.org/doi:10.1126/science.147.3659.747

Liu, Z., \& Pan, J. (2017). A practical method for extending the biuret assay to protein determination of corn-based products. Food Chem, 224, 289-293. http://dx.doi.org/doi:10.1016/j.foodchem.2016.12.084

Lüthy, J., \& Schlatter, C. (1983). Biogene amine in lebensmitteln: Zur Wirkung von histamin, tyramin und phenylethylamin auf den menschen. Z LebensmUnters-Forsch, 177(6), 439-443. http://dx.doi.org/doi:10.1007/BF01409672

Maruo, T., Sakamoto, M., Toda, T., \& Benno, Y. (2006). Monitoring the cell number of Lactococcus lactis subsp. cremoris FC in human feces by real-time PCR with strain-specific primers designed using the RAPD technique. Int J Food Microbiol, 110(1), 69-76. http://dx.doi.org/doi:10.1016/j.ijfoodmicro.2006.01.037 Mohkam, M., Nezafat, N., Berenjian, A., Mobasher, M. A., \& Ghasemi, Y. (2016a). Identification of Bacillus probiotics isolated from soil rhizosphere using 16S rRNA, recA, rpoB gene sequencing and RAPD-PCR. Probiotics Antimicro, 8(1), 8-18. http://dx.doi.org/doi:10.1007/s12602-016-9208-Z

Mohkam, M., Nezafat, N., Berenjian, A., Zamani, M., Dabbagh, F., Bigharaz, R., \& Ghasemi, Y. (2019). Multifaceted toxin profile of Bacillus probiotic in newly isolated Bacillus spp. from soil rhizosphere. Biologia, 1-7. http://dx.doi.org/doi:10.2478/s11756-019-00357-1

Mohkam, M., Rasoul-Amini, S., Shokri, D., Berenjian, A., Rahimi, F., Sadraeian, M., . . . Ghasemi, Y. (2016b). Characterization and in vitro probiotic assessment of potential indigenous Bacillus strains isolated from soil rhizosphere. Minerva Biotechnol, 28(1), 19-28.

Montazeri-Najafabady, N., Ghasemi, Y., Dabbaghmanesh, M. H., Talezadeh, P., Koohpeyma, F., \& Gholami, A. (2018). Supportive Role of Probiotic Strains in Protecting Rats from Ovariectomy-Induced Cortical Bone Loss. Probiotics Antimicro, 1-10. https://doi.org/10.1007/s12602-018-9443-6

Moser, S. A., \& Savage, D. C. (2001). Bile salt hydrolase activity and resistance to toxicity of conjugated bile salts are unrelated properties in lactobacilli. Appl 
Environ Microbiol, 67(8), 3476-3480. https://doi.org/10.1128/aem.67.8.3476$\underline{3480.2001}$

Ortakci, F., \& Sert, S. (2012). Stability of free and encapsulated Lactobacillus acidophilus ATCC 4356 in yogurt and in an artificial human gastric digestion system. J Dairy Sci, 95(12), 6918-6925. https://doi.org/10.3168/jds.2012-5710 Padmavathi, T., Bhargavi, R., Priyanka, P. R., Niranjan, N. R., \& Pavitra, P. V. (2018). Screening of potential probiotic lactic acid bacteria and production of amylase and its partial purification. J Genet Eng Biotechnol, 16(2), 357-362. https://doi.org/doi:10.1016/j.jgeb.2018.03.005

Patel, A. K., Ahire, J. J., Pawar, S. P., Chaudhari, B. L., \& Chincholkar, S. B. (2009). Comparative accounts of probiotic characteristics of Bacillus spp. isolated from food wastes. Food Res Int, 42(4), 505-510. http://dx.doi.org/doi:10.1016/j.foodres.2009.01.013

Rowan, N. J., Deans, K., Anderson, J. G., Gemmell, C. G., Hunter, I. S., \& Chaithong, T. (2001). Putative virulence factor expression by clinical and food isolates of Bacillus spp. after growth in reconstituted infant milk formulae. Appl $\begin{array}{llll}\text { Environ } & \text { Microbiol, } & \text { 67(9), } & \text { 3873-3881. }\end{array}$ http://dx.doi.org/doi:10.1128/AEM.67.9.3873-3881.2001

Saavedra, J. M. (2001). Clinical applications of probiotic agents. Am J Clin Nutr 73(6), 1147S-1151S. https://doi.org/doi:10.1093/ajcn/73.6.1147S

Saha, D., Sundriyal, M., \& Sundriyal, R. (2014). Diversity of food composition and nutritive analysis of edible wild plants in a multi-ethnic tribal land, Northeast India: an important facet for food supply. Indian J Tradit Know, 13(4), 8-12.

Salminen, S., Laine, M., Vonwright, A., Vuopio-Varkila, J., Korhonen, T., \& Mattila-Sandholm, T. (1996). Development of selection criteria for probiotic strains to assess their potential in functional foods: a Nordic and European $\begin{array}{llll}\text { approach. } & \text { Biosci } & \text { Microflora, } & \text { 15(2), }\end{array}$ http://dx.doi.org/doi:10.12938/bifidus1996.15.61

Schillinger, U., Guigas, C., \& Holzapfel, W. H. (2005). In vitro adherence and other properties of lactobacilli used in probiotic yoghurt-like products. Int Dairy J, 15(12), 1289-1297. http://dx.doi.org/doi:10.1016/j.idairyj.2004.12.008

Shokri, D., Khorasgani, M. R., Mohkam, M., Fatemi, S. M., Ghasemi, Y., \& Taheri-Kafrani, A. (2018). The inhibition effect of lactobacilli against growth and biofilm formation of Pseudomonas aeruginosa. Probiotics Antimicro, 10(1), 3442. https://doi.org/10.1007/s12602-017-9267-9

Taheri, H., Moravej, H., Tabandeh, F., Zaghari, M., \& Shivazad, M. (2009). Screening of lactic acid bacteria toward their selection as a source of chicken probiotic. Poultry Sci, 88(8), 1586-1593. http://dx.doi.org/doi:10.3382/ps.200900041

Thapa, N. (2016). Ethnic fermented and preserved fish products of India and Nepal. J Ethn Foods, 3(1), 69-77. https://doi.org/10.1016/j.jef.2016.02.003

Zarei, M., Najafzadeh, H., Eskandari, M. H., Pashmforoush, M., Enayati, A., Gharibi, D., \& Fazlara, A. (2012). Chemical and microbial properties of mahyaveh, a traditional Iranian fish sauce. Food Control, 23(2), 511-514 http://dx.doi.org/doi:10.1016/j.foodcont.2011.08.023 